\title{
Complete genome sequence of a novel secovirid infecting cassava in the Americas
}

\author{
Ana M. Leiva ${ }^{1} \cdot$ Jenyfer Jimenez ${ }^{1} \cdot$ Hector Sandoval $^{2} \cdot$ Shirley Perez ${ }^{2} \cdot$ Wilmer J. Cuellar $^{1}[$
}

Received: 14 July 2021 / Accepted: 24 October 2021 / Published online: 3 January 2022

(c) The Author(s) 2021

\begin{abstract}
We report the complete genome sequence of a field isolate of a novel bipartite secovirid infecting cassava in Colombia, provisionally named "cassava torrado-like virus" (CsTLV). The genome sequence was obtained using Oxford Nanopore Technology, and the 5' ends were confirmed by RACE. The RNA1 is 7252 nucleotides (nt) long, encoding a polyprotein of 2336 amino acids (aa) containing the typical "replication block", conserved torradovirus motifs, and a Maf/Ham1 domain, which is not commonly found in viral genomes. The RNA2 is $4469 \mathrm{nt}$ long and contains two overlapping ORFs encoding proteins of 226 and 1179 aa, showing the characteristic genome arrangement of members of the genus Torradovirus.
\end{abstract}

Cassava torrado-like virus (CsTLV) is a partially characterized member of the family Secoviridae $[1,2]$ that was originally detected in cassava plants (Manihot esculenta Crantz) displaying root symptoms of cassava frogskin disease (CFSD) [3], an endemic disease of cassava in the Americas that can severely affect the root yield of the crop [4]. The virus is found in mixed infections $[3,5]$ and can induce leaf chlorotic spots symptoms in single infections in cassava [2]. Maf/HAM1 proteins are nucleoside triphosphate (NTP) pyrophosphatases that reduce mutagenesis by intercepting non-canonical NTPs and preventing their incorporation into DNA or RNA. They are highly conserved in prokaryotes and eukaryotes [6], but there are only a couple of examples of their presence in viral genomes $[7,8]$.

The complete genome of CsTLV was obtained from a cassava plant of the commercial variety Melua-31, collected in August 2020 in Yopal, Colombia, and total RNA extraction with CTAB was done as reported previously [9]. For library preparation, we followed the SQK-DCS109 protocol (Oxford Nanopore Technologies), which uses RNase

Handling Editor: Ralf Georg Dietzgen.

Wilmer J. Cuellar

w.cuellar@cgiar.org

1 Virology Laboratory, Cassava Program, Crops for Nutrition and Health, International Center for Tropical Agriculture, Palmira, Colombia

2 AGROSAVIA, Centro de Investigacion La Libertad, Sede Yopal, Colombia
Cocktail Enzyme Mix (Thermo Fisher) to eliminate ribosomal RNA. The library was loaded onto a FLO-MIN106 R9.4 flowcell and sequenced for $48 \mathrm{~h}$ in a MinION using MinKnow software v2.0. Basecalling was performed using Guppy v5.0.11, and assembly was performed as described by Leiva et al. [10]. The quality of the consensus sequence obtained was checked using Qualimap v2.2.1 [11], and lowcoverage regions and 5' ends were confirmed by sequencing of overlapping RT-PCR products and using a 5' RACE System for Rapid Amplification of cDNA Ends (Invitrogen).

Excluding the poly-A tail, the RNA1 (OK040225) is $7252 \mathrm{nt}$ long and has a single open reading frame encoding a polyprotein of 2336 aa $(260 \mathrm{kDa})$. It contains the typical "replication block" and a Maf/Ham1 domain at its 3' end at aa 2165 (Fig. 1A). The RNA2 (OK040226) is 4469 nt long and contains two ORFs: RNA2-ORF1 is $678 \mathrm{nt}$ long and encodes a predicted protein of 226 aa $(25 \mathrm{kDa})$. RNA2-ORF2 is $3534 \mathrm{nt}$ long and overlaps with $44 \mathrm{nt}$ of the 3' end of RNA2-ORF1; it encodes a predicted polyprotein of 1179 aa $(131 \mathrm{kDa})$ containing the $3 \mathrm{~A} / \mathrm{RNA} 2$ movement protein domain (A3) and three coat proteins domains. The sequence obtained showed more than $98 \%$ aa sequence identity to all other partial CsTLV sequences available in the GenBank database, and BLASTp analysis revealed the highest aa sequence identity to squash chlorotic leaf spot virus (NC_035221; NC_035222), with 37.75\% aa sequence identity and $82 \%$ coverage for RNA1 and $45.53 \%$ sequence aa identity and $77 \%$ coverage for RNA2.

Maf/Ham1 domains have only been reported in potyvirids. The first one was discovered by Mbanzibwa et al. 


\section{A}

RNA1 (7252 nt)

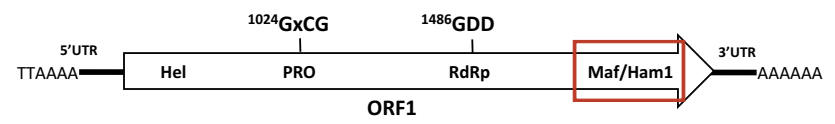

B

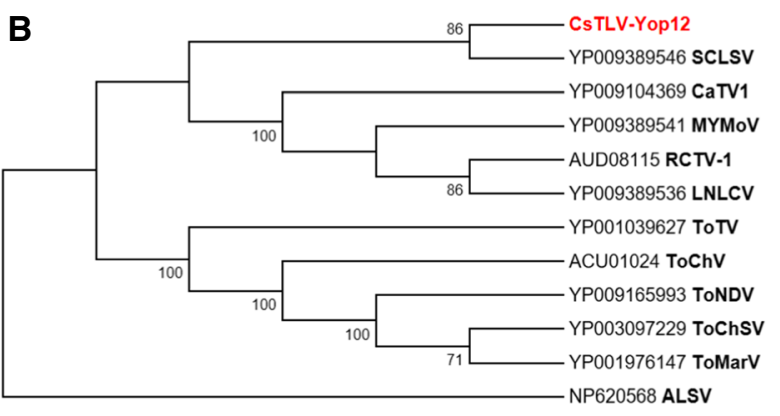

$\longrightarrow .2$

Fig. 1 (A) Genome organization of CsTLV isolate Yop12 showing the location of conserved consensus motifs shared by torradoviruses [1] and the Maf/Ham1 domain (red frame). (B) Phylogenetic relationships of CsTLV to members of the genus Torradovirus, analyzed

[7] while working on the characterization of a Tanzanian isolate of cassava brown streak virus (genus Ipomovirus) (GenBank accession no. FJ039520.1), and a second one was reported by Knierim et al. [8] in a German isolate of euphorbia ringspot virus (genus Potyvirus) (GenBank accession no. NC_031339.1) (Fig. 2). Recently, Tomlinson et al. [12] demonstrated the activity of the potyvirid Maf/Ham1 in yeast and uncovered their role as a necrosis determinant in Nicotiana benthamiana, and James et al. [13] have suggested possible functions for this domain. In conclusion, CsTLV is
RNA2 (4469 nt)
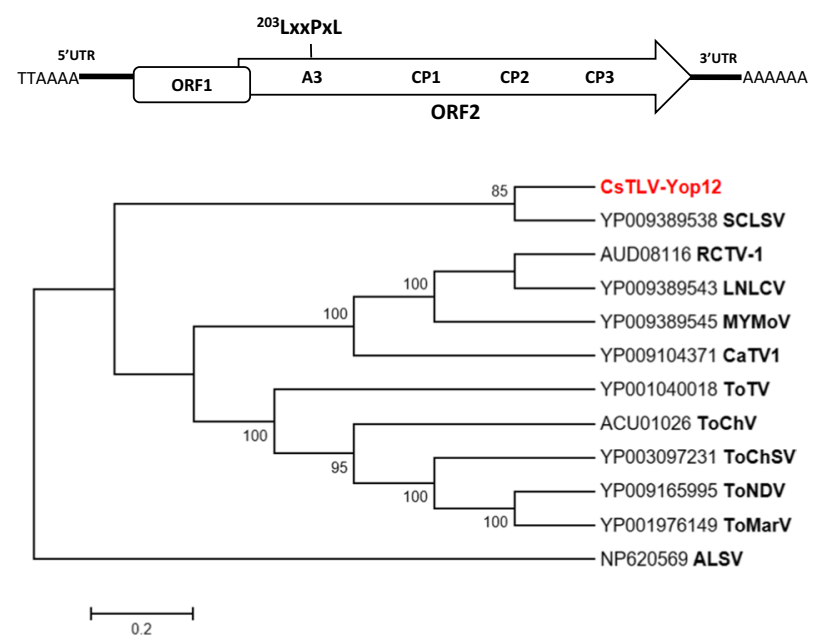

using the aa sequences of RNA1 and RNA2 polyproteins. The phylogenetic tree was generated by the neighbor-joining method using MEGA. The evolutionary distances were computed using the Poisson correction method (number of aa substitutions per site).

an atypical secovirid encoding a Maf/Ham1 protein domain, which has been described so far only in viruses infecting euphorbiaceous hosts $[2,7,8]$. Further studies are underway to determine the biological role of CsTLV Maf/Ham1 in the virus infection cycle in cassava. 


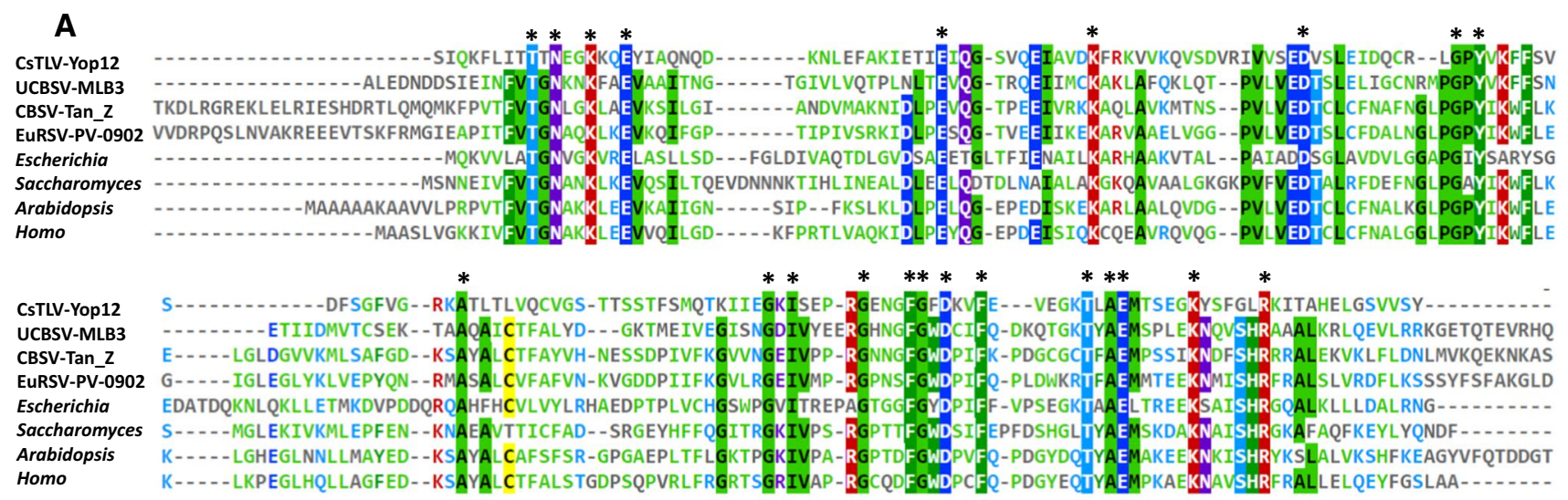

B

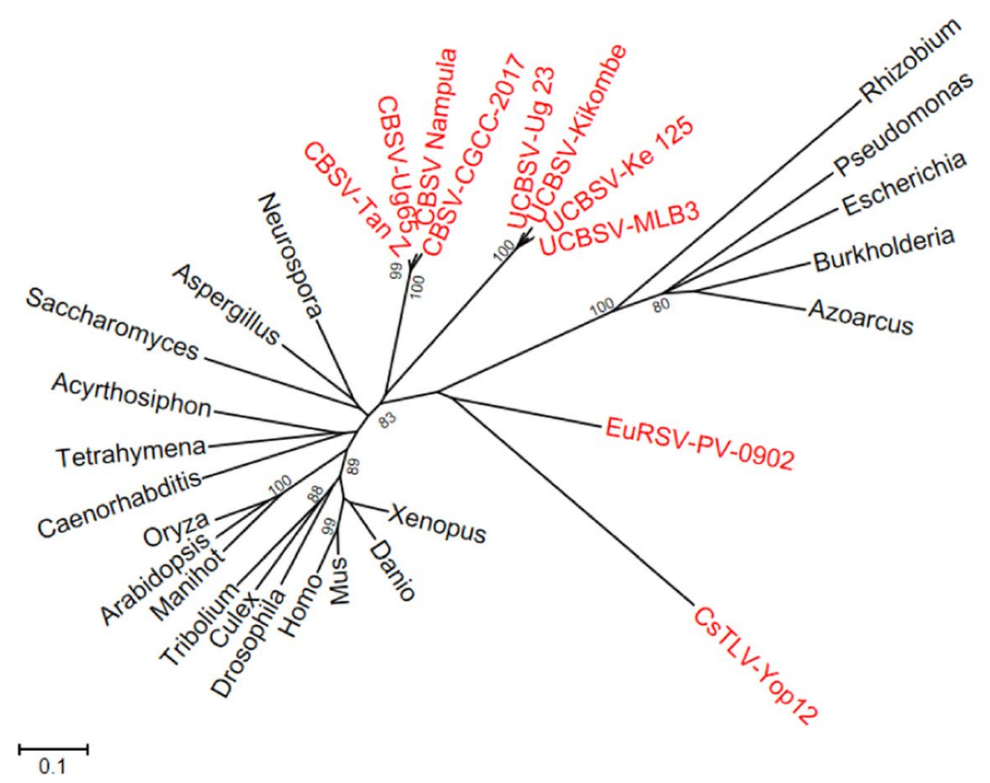

Fig. 2 (A) Sequence alignment showing the conserved sites of Maf/Ham1 domains from different taxa. The figure was made using Mview [14]. (B) Phylogenetic relationships of the Maf/ Ham1 domain. Viruses (in red): EuRSV-PV-0902, YP_009305422; CBSV-Nampula, AYW01246; CBSV-Tan_Z, ACT78701; CBSV-Ug65, QGW67508; CBSV-CGCC-2017, QCR98745; UCBSV-Kikombe, ARQ80023; UCBSV-MLB3, ACM48176; UCBSV-Ug_23, CBA18486; UCBSV-Ke_125, ASG92173; CsTLVYop12, ??OK040225??; Escherichia 1K7K_A; Pseudomonas,

Supplementary Information The online version contains supplementary material available at https://doi.org/10.1007/s00705-021-05325-2.

Acknowledgements We are grateful to all our colleagues from the Virology Lab and the Cassava Program of CIAT. Special thanks to Dr. Amparo Rosero from Agrosavia and Dr. Diana Lopez-Alvarez from Universidad Nacional de Colombia, Palmira, for supporting this work. This research was co-funded by the CGIAR Research Program on Roots, Tubers, and Bananas (CRP-RTB) (https://www.cgiar.org/ funders).

Author contributions AML carried out nanopore sequencing and analysis. JJ, HS, and SP performed molecular diagnostics, 5'RACE, and
WP 011064019; Burkholderia, KHS13049; Azoarcus, CAL96580; Rhizobium, CAK05869; Saccharomyces, CAA89597; Aspergillus, XP_754075; Neurospora, XP_955963; Arabidopsis, NP_567410; Oryza, XP_015613001; Manihot, XP_021594792; Caenorhabditis, AAL14111; Tetrahymena, XP_977249; Acyrthosiphon, NP_001233079; Drosophila, EDV32196; Culex, XP_038111262; Tribolium, XP_974197; Xenopus, AAI10772; Danio, NP_001093456; Mus, EDL28288; Homo, AAK21848

field activities. WJC designed the research, supervised the work, and wrote the manuscript. All authors approved the manuscript.

Funding CGIAR Research Program on Roots, Tubers, and Bananas

Availability of data and material Sequence data have been submitted to the GenBank database.

\section{Declarations}

Conflict of interest The authors declare no conflict of interest. 
Open Access This article is licensed under a Creative Commons Attribution 4.0 International License, which permits use, sharing, adaptation, distribution and reproduction in any medium or format, as long as you give appropriate credit to the original author(s) and the source, provide a link to the Creative Commons licence, and indicate if changes were made. The images or other third party material in this article are included in the article's Creative Commons licence, unless indicated otherwise in a credit line to the material. If material is not included in the article's Creative Commons licence and your intended use is not permitted by statutory regulation or exceeds the permitted use, you will need to obtain permission directly from the copyright holder. To view a copy of this licence, visit http://creativecommons.org/licenses/by/4.0/.

\section{References}

1. van der Vlugt RAA, Verbeek M, Dullemans AM, Wintermantel WM, Cuellar WJ, Fox A, Thompson JR (2015) Torradoviruses. Ann Rev Phytopathol 53:485-512. https://doi.org/10.1146/annur ev-phyto-080614-120021

2. Jimenez J (2017) Caracterización del virus Cassava torrado-like virus en yuca (Manihot esculenta Crantz) e identificación de proteínas virales involucradas en la supresión del silenciamiento de ARN. MSc Thesis in Biological Sciences. Universidad Nacional de Colombia-Sede Palmira. https://repositorio.unal.edu.co/handle/unal/63749

3. Carvajal-Yepes M, Olaya C, Lozano I, Cuervo M, Castaño M, Cuellar WJ (2014) Unraveling complex viral infections in cassava (Manihot esculenta Crantz) from Colombia. Virus Res 186:76-86. https://doi.org/10.1016/j.virusres.2013.12.011

4. Carvalho MJS, Oliveira EJ, Souza AS, Pereira JS, Diamantino MSAS, Oliveira SAS (2017) Cleaning cassava genotypes infected with cassava frogskin disease via in vitro shoot tip culture. Genet Mol Res 16:gmr16029556. https://doi.org/10.4238/gmr16029556

5. de Oliveira SAS, Ferreira CF, Diamantino MSAS et al (2020) First report of cassava torrado-like virus, cassava polero-like virus and cassava new alphaflexivirus associated with cassava frogskin disease in Brazil. J Plant Pathol 102:247. https://doi.org/10.1007/ s42161-019-00384-6

6. Galperin MY, Moroz OV, Wilson KS, Murzin AG (2006) Housecleaning, a part of good housekeeping. Mol Microbiol 59:5-19. https://doi.org/10.1111/j.1365-2958.2005.04950.x
7. Mbanzibwa DR, Tian Y, Mukasa SB, Valkonen JPT (2009) Cassava Brown Streak Virus (Potyviridae) encodes a putative Maf/ Ham1 pyrophosphatase implicated in reduction of mutations and a P1 proteinase that suppresses RNA silencing but contains no HCPro. J Virol 83:6934-6940. https://doi.org/10.1128/jvi.00537-09

8. Knierim D, Menzel W, Winter S (2017) Analysis of the complete genome sequence of euphorbia ringspot virus, an atypical member of the genus Potyvirus. Arch Virol 162:291-293. https://doi.org/ 10.1007/s00705-016-3087-1

9. Jimenez J, Leiva AM, Olaya C, Acosta-Trujillo D, Cuellar WJ (2021) An optimized nucleic acid isolation protocol for virus diagnostics in cassava (Manihot esculenta Crantz.). MethodsX 8:101496. https://doi.org/10.1016/j.mex.2021.101496

10. Leiva AM, Siriwan W, Lopez-Alvarez D, Barrantes I, Hemniam N, Saokham K, Cuellar WJ (2020) Nanopore-based complete genome sequence of a Sri Lankan cassava mosaic virus strain from Thailand. Microbiol Res Announce 9:e01274-e1319. https://doi.org/10.1128/MRA.01274-19

11. Okonechnikov K, Conesa A, García-Alcalde F (2016) Qualimap 2: advanced multi-sample quality control for high-throughput sequencing data. Bioinformatics 32:292-294. https://doi.org/ 10.1093/bioinformatics/btv566

12. Tomlinson KR, Pablo-Rodriguez JL, Bunawan H, Nanyiti S, Green P, Miller J, Alicai T, Seal SE, Bailey AM, Foster GD (2019) Cassava brown streak virus Ham 1 protein hydrolyses mutagenic nucleotides and is a necrosis determinant. Mol Plant Pathol 20:1080-1092. https://doi.org/10.1111/mpp.12813

13. James AM, Seal SE, Bailey AM, Foster GD (2020) Viral inosine triphosphatase: a mysterious enzyme with typical activity, but atypical function. Mol Plant Pathol 22:382-389. https://doi.org/ 10.1111/mpp.13021

14. Brown NP, Leroy C, Sander C (1998) MView: a web-compatible database search or multiple alignment viewer. Bioinformatics 14:380-381. https://doi.org/10.1093/bioinformatics/14.4.380

Publisher's Note Springer Nature remains neutral with regard to jurisdictional claims in published maps and institutional affiliations. 